\title{
Does Tourism Boost Economic Growth: Evidence from Italy
}

Submitted 19/06/20, $1^{\text {st }}$ revision $25 / 07 / 20,2^{\text {nd }}$ revision $18 / 08 / 20$, accepted $15 / 09 / 20$

\section{Uzma Khan $^{1}$}

\begin{abstract}
:
Purpose: Tourism plays a crucial role in enhancing the nation's welfare. Therefore, this study's core idea is to investigate tourist arrival, tourism growth, tourism expenditure, and its associated economic headway impact.

Approach/Methodology/Design: Using an annual time series data from 1995-2018, capturing the effect of tourism growth, tourism expenditure on economic growth, and finally revealing the association amongst these endogenous and exogenous parameters.

Findings: The unit root test analysis outcomes illustrate that all parameters become stationary when a first-order difference is considered as having a lag value of one. ADRL Bound test reveals the presence of short-run association among parameters. The outcomes of $t$-statistics and the Wald $F$-test reveal bidirectional and unidirectional causation among the parameters.
\end{abstract}

Practical Implications: The study will contribute positively to the understanding of tourism and its associated effect to boost the economy.

Originality/Value: The study believes to contribute positively to the understanding of the tourism sector.

Keywords: Tourism growth, tourism expenditure, economic growth, ARDL bound test.

JEL classification: C01, C22, O11.

Paper Type: Case study.

ISSN: 2241-4754, H index 10, Q3.

\footnotetext{
${ }^{1}$ Department of Finance, College of Business Administration, Prince Sattam Bin Abdul Aziz University, Al-kharj, Riyadh, Kingdom of Saudi Arabia,uzmakhanafridi@gmail.com; u.khan@psau.edu.sa; ORCID ID: 0000-0002-7248-090X.
} 


\section{Introduction}

Nowadays, tourism is considered a significant category of international trade in services and has become one of the most noticeable and growing sectors. Tourism encompasses the growth and development of a country: firstly, by bringing multiple economic values and benefits and, secondly, helping to build a country's brand value, image, and identity. It is an essential component of export diversification for emerging and advanced economies, with a strong capacity to reduce trade deficits and compensate for weaker export revenue from other goods and services. Italy ranks 5 th in tourist arrivals and ranks 6th in tourist receipts (UNWTO, 2019). It contributes $13.0 \%$ to Italian GDP with a growth of $2.2 \%$ and $0.1 \%$ in real economy GDP growth compared to the previous year. The global economy grew by $2.5 \%$, travel and tourism grew significantly more at $3.5 \%$, out of 4 new jobs, one job created by tourism. About $14.9 \%$ of total employment is contributed by tourism in Italy (WTTC, 2019).

By appealing international tourists, tourism contributes to bringing foreign exchange earnings, which generates employment, improved infrastructure, and quality of life, which in turn help in the sustainable economic growth of that particular country as tourist contribute to sales, profits, jobs, tax revenue and income in an area.

\section{Literature Review}

The expansion of tourism has been recognized globally as a catalyst for economic growth, agriculture and energy development, and poverty mitigation. Oh (2005) suggested a one-way causal association of economic growth that leads to tourism growth. Samina et al. (2007) felt that there is a strong link between tourism receipts and economic growth, and economic expansion is essential for tourism development. Fayissa et al. (2007) witnessed that tourism receipts could significantly impact the current GDP and economic growth. Akan et al. (2008) explored the cause and effect link between tourism and economic expansion. Further, they found that tourism had strongly affected by economic expansion. Kreishan (2011) empirically investigated the tourism-led-growth hypothesis (TLGH) and identified a favourable bond among tourism progress and economic expansion; further, he revealed a one-way Granger causality flowing from tourism progress to economic expansion. Wang (2015) found a strong association between the GDP and tourist income in Guihoz, China.

Bayramoglu and Ari (2015) acknowledged a positive one-way causality from foreign tourists' expenditures to economic growth. Tang (2015) indicated that tourism causes Malaysian economic development in both the short and long-run. Ahad (2016) advocated a tourism-led growth for Pakistan and discovered a dual association between tourism expenditure and economic progress. Phiri (2016) stressed that tourism should be gradually recognized as an essential element of economic progress and expansion and established tourism-led development where tourism receipts acted as a tool to expand tourism. Ohlan (2017) discovered long-run one-way causation 
running from tourism to economic growth. Tabash (2017) similarly found a unique long-term connection between tourism receipts and economic growth.

Blanka and Zyonimir (2016) claimed that tourism leads to development when tourist receipts are used to assess tourism development. Similarly, Chris (2015) and Leit-Ao and Shahbaz (2016) exposed that tourist arrivals and tourism receipts are strongly linked to economic expansion. Dogru and Bulut (2018) revealed a both-ways causality between tourism receipts and economic development. Usmani et al. (2020) established that tourist expenditure has a strong influence on economic progress, while tourist arrivals do not significantly impact. Further, they found dual causality running between tourist expenditure and economic progress. Khan et al. (2020) highlighted the importance of tourism in the expansion of emerging economies, while Adamopoulos and Thalassinos (2020) studied tourism and economic growth in the G-6 countries.

This study's core idea is to create an econometric model that investigates the link between tourist arrival, tourism growth, tourism expenditure, and Italy's economic growth.

\section{Methodology}

Annual time series from 1995 to 2018 are taken in our study, which should be sufficient to capture the association between tourism growth (measured in terms of tourism receipt), tourism expenditure (measured in terms of tourism expenditure), and economic growth (measured in terms of GDP) in this model.

The macroeconomic model is formulated using the variable to investigate the causal association among the variable as:

Economic growth $=f$ (tourist arrival, tourism growth, tourism expenditure)

Tourist arrival

Tourism growth

$$
=f \text { (economic growth, tourism growth,tourism expenditure) }
$$

$$
\begin{aligned}
& =f(\text { economic growth, tourist arrival, tourism expenditure) } \\
& \text { Tourism expenditure } \\
& =f(\text { economic growth, tourist arrival, tourism growth) }
\end{aligned}
$$

All the variables are used in a real term and transformed into logarithmic function:

$$
L Y_{t}=\log \left(Y_{t}\right)
$$

Long run Model can be expressed as:

$$
\operatorname{lng} g_{t}=\emptyset_{01}+b_{11} \operatorname{lng}_{t-1}+b_{21} \ln a_{t-1}+b_{31} \ln e_{t-1}+b_{41} \ln r_{t-1}+e_{1 t}
$$


Short run Model can be expressed as:

$$
\begin{aligned}
\Delta l n g_{t}=\partial_{01}+ & \sum_{i=1}^{p} \partial_{1 i} \Delta \ln g_{t-i}+\sum_{i=1}^{q} \partial_{2 i} \Delta \ln a_{t-i}+\sum_{i=1}^{q} \partial_{3 i} \Delta \ln e_{t-i} \\
& +\sum_{i=1}^{q} \partial_{4 i} \Delta \ln r_{t-i}+\varepsilon_{1 t} \\
\Delta l n a_{t}=\partial_{02}+ & \sum_{i=1}^{p} \partial_{1 i} \Delta \ln a_{t-i}+\sum_{i=1}^{q} \partial_{2 i} \Delta \operatorname{lng} g_{t-i}+\sum_{i=1}^{q} \partial_{3 i} \Delta \ln e_{t-i} \\
& +\sum_{i=1}^{q} \partial_{4 i} \Delta \ln r_{t-i}+\varepsilon_{1 t} \\
\Delta \ln e_{t}=\partial_{03}+ & \sum_{i=1}^{p} \partial_{1 i} \Delta \ln e_{t-i}+\sum_{i=1}^{q} \partial_{2 i} \Delta \operatorname{lng} g_{t-i}+\sum_{i=1}^{q} \partial_{3 i} \Delta \ln a_{t-i} \\
& +\sum_{i=1}^{q} \partial_{4 i} \Delta \ln r_{t-i}+\varepsilon_{1 t} \\
\Delta \ln r_{t}=\partial_{03}+ & \sum_{i=1}^{p} \partial_{1 i} \Delta \ln r_{t-i}+\sum_{i=1}^{q} \partial_{2 i} \Delta \operatorname{lng} g_{t-i}+\sum_{i=1}^{q} \partial_{3 i} \Delta \ln a_{t-i} \\
& +\sum_{i=1}^{q} \partial_{4 i} \Delta \ln e_{t-i}+\varepsilon_{1 t}
\end{aligned}
$$

Where; lng; represents the log value of economic growth, lna; represents the log value of number of tourist arrival; lne; represents the log value of tourism expenditure, lnr; represents log value of tourism growth, $\partial$ is the coefficient and $\varepsilon$; represents the error.

\section{Empirical Analysis}

\begin{tabular}{|c|c|c|c|c|c|}
\hline & 1 & \multicolumn{2}{|l|}{$\mathrm{ADF}$} & \multicolumn{2}{|c|}{ Phillips-Perron } \\
\hline & & t-statistic & Prob. & Adj. t-stat. & Prob. \\
\hline
\end{tabular}

Table 1 represents the lag selection criterion to be at one lag order. The unit root tests indicate the first difference level of significance as disclose in Table 2. However, Table 3 depicts the conclusion of the ARDL bound test.

Table 1. VAR lag order selection criterion

\begin{tabular}{|l|l|l|l|l|l|l|} 
Lag & LogL & LR & FPE & AIC & SC & HQ \\
\hline 0 & 72.36967 & NA & $2.35 \mathrm{E}-08$ & -6.21543 & -6.21543 & -6.1687 \\
\hline 1 & 135.5803 & $97.68911 *$ & $3.32 \mathrm{E}-10^{*}$ & $-10.5073 *$ & $-9.51544 *$ & $-10.2737 *$ \\
\hline 2 & 149.6424 & 16.61882 & $4.70 \mathrm{E}-10$ & -10.3311 & -8.54578 & -9.91055 \\
\hline
\end{tabular}

Source: Author's Computation.

Table 2. Unit Root Test 


\begin{tabular}{|l|l|l|l|l|l|}
\multirow{2}{*}{ LNG } & Level & -1.3185 & 0.603 & -1.3483 & 0.589 \\
\cline { 2 - 6 } & 1st Difference & -3.6695 & $0.0125^{* *}$ & -3.7036 & $0.0116^{* *}$ \\
\hline \multirow{2}{*}{ LNA } & Level & -0.0788 & 0.9408 & 0.04197 & 0.9534 \\
\cline { 2 - 6 } & 1st Difference & -4.317 & $0.003^{*}$ & -4.3549 & $0.0027^{*}$ \\
\hline \multirow{2}{*}{ LNE } & Level & -1.5088 & 0.5114 & -1.4639 & 0.5334 \\
\cline { 2 - 6 } & 1st Difference & -5.2813 & $0.0003^{*}$ & -5.2803 & $0.0003^{*}$ \\
\hline \multirow{2}{*}{ LNR } & Level & -0.5453 & 0.8646 & -0.5453 & 0.8646 \\
\cline { 2 - 6 } & 1st Difference & -3.4628 & $0.0194^{* *}$ & -3.3934 & $0.0225^{* *}$ \\
\hline \hline
\end{tabular}

Note: $* * *$ represents $1 \%$ and $5 \%$ significance level

Source: Author's computation.

Table 3. Summary of Bound Test (Unrestricted Const. \& No Trend)

\begin{tabular}{|l|l|l|l|l|} 
& F-Statistics & t-statistics & Cointegration & Inference \\
\hline LNG & 2.143032 & -1.96563 & No & Estimation of ARDL(Short-run) \\
\hline LNA & 2.27455 & -1.4349 & No & Estimation of ARDL(Short-run) \\
\hline LNE & 3.20192 & -3.4179 & No & Estimation of ARDL(Short-run) \\
\hline LNR & 1.95266 & -1.8329 & No & Estimation of ARDL(Short-run)
\end{tabular}

Table 4. Regressors t-statistic and Wald coefficient test

\begin{tabular}{|c|c|c|c|c|c|c|c|}
\hline & & \multicolumn{2}{|l|}{ t-statistic } & \multicolumn{4}{|c|}{ Wald F-Statistic } \\
\hline & & t-statistic & Prob. & F-statistic & Prob. & Chi-square & Prob. \\
\hline \multirow[b]{5}{*}{ LNG } & LNA & -2.52335 & $0.0226 * *$ & \multirow[b]{2}{*}{3.706162} & \multirow[b]{2}{*}{$0.0476^{* *}$} & \multirow[b]{2}{*}{7.412323} & \multirow[b]{2}{*}{$0.0246 * *$} \\
\hline & LNA(-1) & 1.844786 & $0.0837 * * *$ & & & & \\
\hline & LNE & -1.50752 & 0.1512 & 2.272613 & 0.1512 & 2.272613 & 0.1317 \\
\hline & LNR & 8.020295 & $0.00^{*}$ & & & & \\
\hline & LNR(-1) & -2.5087 & $0.0233 * *$ & 32.28077 & $0.00 *$ & 64.56154 & $0.00 *$ \\
\hline \multirow[b]{3}{*}{ LNA } & LNE & -1.0498 & 0.3077 & 1.102165 & 0.3077 & 1.102165 & 0.2938 \\
\hline & LNR & 2.844023 & $0.0108 * *$ & 8.088466 & $0.0108 * *$ & 8.088466 & $0.0045^{*}$ \\
\hline & LNG & -2.32749 & $0.0318 * *$ & 5.41721 & $0.0318 * *$ & 5.41721 & $0.0199 * *$ \\
\hline \multirow[b]{3}{*}{ LNE } & LNR & 2.172219 & $0.0434 * *$ & 4.718536 & $0.0434 * *$ & 4.718536 & $0.0298 * *$ \\
\hline & LNG & -2.9014 & $0.0095^{*}$ & 8.418141 & $0.0095^{*}$ & 8.418141 & $0.0037^{*}$ \\
\hline & LNA & -0.67055 & 0.511 & 0.449637 & 0.511 & 0.449637 & 0.5025 \\
\hline \multirow[b]{5}{*}{ LNR } & LNG & 8.020295 & $0.00^{*}$ & \multirow[b]{2}{*}{32.17874} & \multirow[b]{2}{*}{$0.00 *$} & \multirow[b]{2}{*}{64.35748} & \multirow[b]{2}{*}{$0.00^{*}$} \\
\hline & LNG(-1) & -2.882 & $0.0108 * *$ & & & & \\
\hline & LNA & -2.882 & $0.0151 * *$ & \multirow[b]{2}{*}{4.941062} & \multirow[b]{2}{*}{$0.0213 * *$} & \multirow[b]{2}{*}{9.882124} & \multirow[b]{2}{*}{$0.0071^{*}$} \\
\hline & $\operatorname{LNA}(-1)$ & 2.719796 & $0.0873 * * *$ & & & & \\
\hline & LNE & 1.110541 & 0.2832 & 1.2333 & 0.2832 & 1.2333 & 0.2668 \\
\hline
\end{tabular}

If there is no co-integration, the ARDL ( $\left.\mathrm{p}, \mathrm{q}_{1}, \mathrm{q}_{2}\right)$ model can be estimated as:

$$
\begin{aligned}
& \Delta l n g_{t}=0.015422+0.207925 \Delta \ln g_{t-i}+0.010498 \Delta \ln a_{t-i}+0.06417 \Delta \ln e_{t-i} \\
& +0.038614 \Delta \ln r_{t-i}+\varepsilon_{1 t} \\
& \Delta \ln a_{t}=0.028713+0.071433 \Delta \ln a_{t-i}-0.075786 \Delta \operatorname{lng} g_{t-i}-0.040038 \Delta \ln e_{t-i} \\
& -0.11746 \Delta \ln r_{t-i}+\varepsilon_{2 t} \\
& \Delta \ln _{t}=0.006325-0.157043 \Delta \ln e_{t-i}-0.531738 \Delta \operatorname{lng} g_{t-i} \\
& -0.507197 \Delta \ln a_{t-i}+0.592873 \Delta \ln r_{t-i}+\varepsilon_{3 t}
\end{aligned}
$$




$$
\begin{gathered}
\Delta l n r_{t}=0.018926+0.234809 \Delta \ln r_{t-i}+0.03939 \Delta \operatorname{lng} g_{t-i}-0.070443 \Delta \ln a_{t-i} \\
+0.118204 \Delta \ln e_{t-i}+\varepsilon_{4 t}
\end{gathered}
$$

\begin{tabular}{|c|c|c|}
\hline Dependent & t-statistics & Wald F-test \\
\hline \multirow[b]{2}{*}{ LNG } & lna: Significant & lna: Significant \\
\hline & lnr: Significant & lnr: Significant \\
\hline \multirow[b]{2}{*}{ LNA } & lnr: Significant & lnr: Significant \\
\hline & lng: Significant & lng: Significant \\
\hline \multirow[b]{2}{*}{ LNE } & lnr: Significant & lnr: Significant \\
\hline & lng: Significant & lng: Significant \\
\hline \multirow[b]{2}{*}{ LNR } & lna: Significant & lna: Significant \\
\hline & lng: Significant & lng: Significant \\
\hline
\end{tabular}

Table 5. Summary of t-statistics \& Wald test

Source: Author's computation.

As demonstrated in Tables 4 and 5, the outcomes of t-statistic, F-statistic, and Chisquare show that all the p-values are below 5\%. Hence, we cannot reject the null hypothesis and reveal a short-run causality among the parameters. Table 6 and Figure1 disclose that the entire model is well specified and dynamically stable.

\begin{tabular}{|c|c|c|c|c|}
\hline Dependent & \multicolumn{3}{|c|}{ Breusch-Godfrey Serial Correlation LM Test } & \multirow{4}{*}{$\begin{array}{l}\text { Inference } \\
\text { The null hypothesis of } \\
\text { no serial correlation } \\
\text { could not be rejected. }\end{array}$} \\
\hline \multirow[b]{2}{*}{ LNG } & F-statistic & 1.439398 & $(0.2477)$ & \\
\hline & Obs*R-sq & 1.815817 & $(0.1778)$ & \\
\hline \multirow[b]{2}{*}{ LNA } & F-statistic & 0.096681 & $(0.7599)$ & \\
\hline & Obs*R-sq & 0.132138 & $(0.7162)$ & \\
\hline \multirow[b]{2}{*}{ LNE } & F-statistic & 0.317754 & $(0.5808)$ & \\
\hline & Obs*R-sq & 0.428404 & $(0.5128)$ & \\
\hline \multirow{3}{*}{ LNR } & F-statistic & 0.359946 & $(0.5572)$ & \\
\hline & Obs $* \mathrm{R}-\mathrm{sq}$ & 0.48338 & $(0.4869)$ & \\
\hline & \multicolumn{3}{|c|}{ Breusch-Pagan-Godfrey Heteroskedasticity Test } & Inference \\
\hline \multirow[b]{2}{*}{ LNG } & F-statistic & 0.289007 & $(0.8811)$ & \multirow{8}{*}{$\begin{array}{l}\text { The null hypothesis of } \\
\text { no heteroskedasticity } \\
\text { could not be rejected. }\end{array}$} \\
\hline & Obs*R-sq & 1.400779 & $(0.8441)$ & \\
\hline \multirow[b]{2}{*}{ LNA } & F-statistic & 0.358175 & $(0.8348)$ & \\
\hline & Obs*R-sq & 1.709972 & $(0.7889)$ & \\
\hline \multirow[b]{2}{*}{ LNE } & F-statistic & 1.372768 & $(0.2848)$ & \\
\hline & Obs*R-sq & 5.371178 & $(0.2513)$ & \\
\hline & F-statistic & 0.849095 & $(0.5136)$ & \\
\hline LNR & Obs*R-sq & 3.663412 & $(0.4535)$ & \\
\hline LNG & Jarque-Bera & 0.428671 & $(0.807078)$ & \multirow{4}{*}{$\begin{array}{l}\text { The null hypothesis of } \\
\text { normal distribution } \\
\text { could not be rejected. }\end{array}$} \\
\hline LNA & Jarque-Bera & 0.634744 & $(0.72806)$ & \\
\hline LNE & Jarque-Bera & 1.122365 & $(0.570534)$ & \\
\hline LNR & Jarque-Bera & 0.932013 & $(0.627503)$ & \\
\hline
\end{tabular}

Table 6. Summary of Diagnostic Test 
Source: Author's computation.

Figure1. Recursive estimates- CUSUM \& CUSUM Sq.
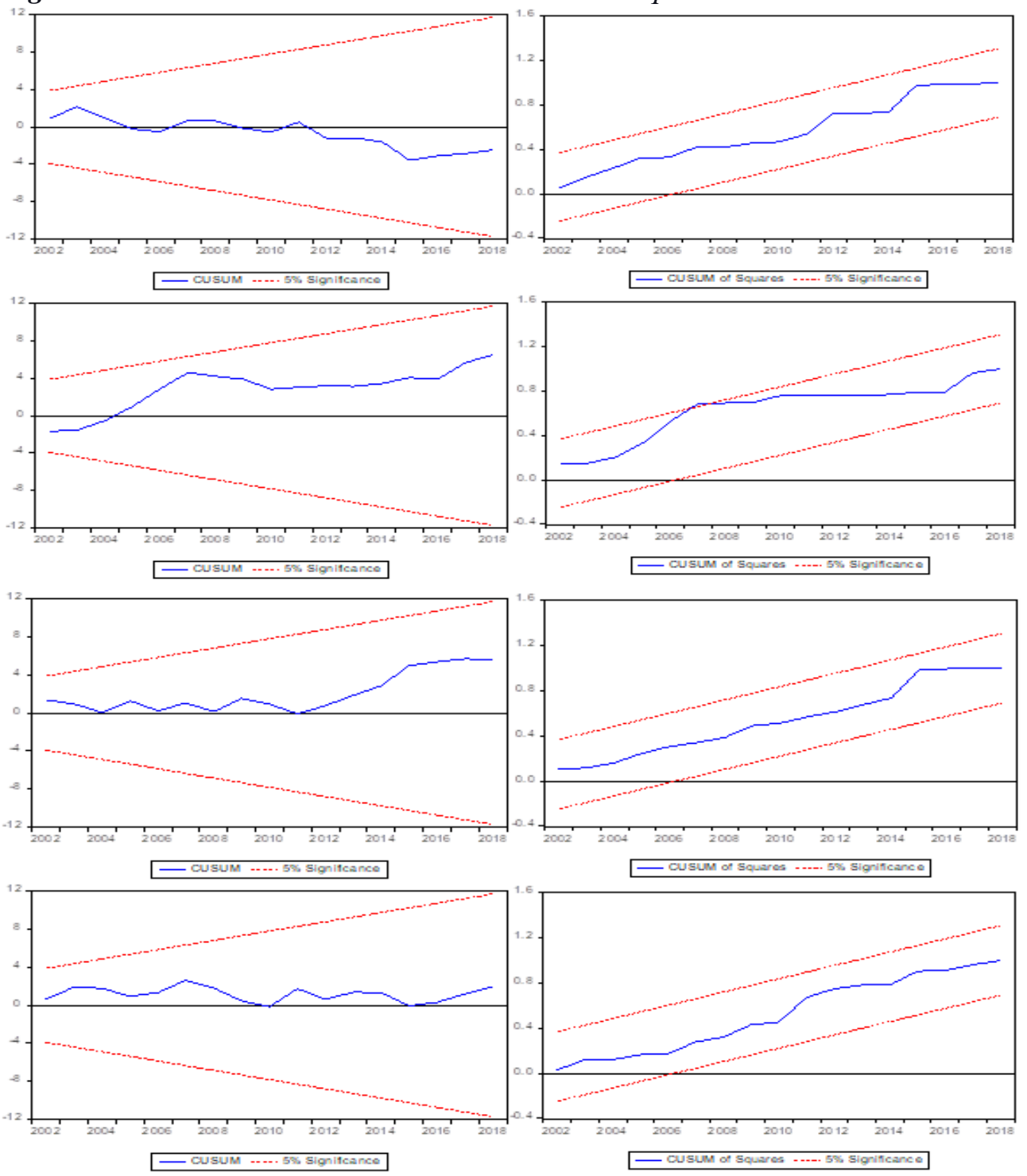

Source: Author's results.

\section{Conclusion}

The current study is based on a two-fold investigation method. Firstly, it investigates the association among the parameters. Secondly, if such an association exhibits tried to explore the causality. Empirical results reveal short-run association among the 
parameters, t-statistic and Wald F-statistic discloses dual causation among economic growth to tourism growth, and economic growth to tourist arrivals, while one-way causation among economic growth to tourism expenditure, tourism growth to tourism expenditure, and no causal association among tourist arrivals and tourism expenditure. The diagnostic test reveals that the entire model is well specified and dynamically stable.

\section{References:}

Ahad, M. 2016. Does Tourism-led Growth Hypothesis exist in Pakistan? A fresh look from Combine Co-integration and Causality Approach with Structural Breaks. International Journal of Economics and Empirical Research, 4(2), 94-111.

Akan, Y., Arslan, I., S1k, U.C. 2008. The Impact of Tourism on Economic Growth: The Case of Turkey. J. Tour, 9, 47-69.

Adamopoulos, A., Thalassinos, I.E. 2020. Tourism Development and Economic Growth: A Comparative Study for the G-6 Leaders. European Research Studies Journal, 23(1), 368-380. DOI: 10.35808/ersj/1555.

Bayramoglu, T., Ari, Y.O. 2015. The relationship between tourism and economic growth in Greece economy: a time series analysis. Computational Method in Social Sciences. 3(1), 89-93.

Blanka, S., Zyonimir, K. 2016. Tourism and economic growth in the Mediterranean region: Dynamic panel data approach. Acta Economica Et Turistica, Sciendo, 2(1), 65-84.

Chris, A.O. 2015. Prospects and problems of sustainable tourism in Nigeria. International Journal of Management Science, 6(11), 508-514.

Dogru, T., Bulut, U. 2018. Is tourism an engine for economic recovery? Theory and empirical evidence. Tourism Management, 67, 425-434.

Fayissa, B., Nsiah, C., Tadasse, B. 2007. The impact of Tourism on Economic Growth and Development in Africa. Tourism Economics, 14(4), 807-818.

Khan, A., Bibi, S., Lorenzo, A., Lyu, J., Baber, Z.U. 2020. Tourism and Development in Developing Economies: A Policy Implication Perspective. Sustainability, 12(4), 01-19.

Kreishan, F.M. 2011. Empirical Study of Tourism and Economic Growth of Bahrain: An ARDL Bounds Testing Approach. International Journal of Economics and Finance, 7(11), 1-9.

Leit-Ao, N.C., Shahbaz, M. 2016. Economic growth, tourism arrivals and climate change. Bulletin of Energy Economics (BEE). The Economics and Social Development Organization, 4(1), 35-43.

Martin, H. 2019. Tourism: The Sultanate's next chapter. Retrieved from https://timesofoman.com/article/785210

Oh, C. 2005. The contribution of tourism development to economic growth in the Korean economy. Tourism Management. 26(1), 39-44.

Ohlan, R. 2017. The relationship between tourism, financial development, and economic growth in India. Future Business Journal, 3(1), 9-22.

Phiri, A. 2016. Tourism and economic growth in South Africa: Evidence from linear and nonlinear cointegration frameworks. Managing Global Transitions, University of Primorska, Faculty of Management Koper, 14(1), 31-53. 
Samina, K., Kakar, M.K., Waliullah. 2007. Role of tourism in Economic Growth: Empirical Evidence from Pakistan Economy. The Pakistan Development Review, 46(4), 985995.

Shakouri, B., Yazdi. S.K., Nategian, N., Shikhrezaei, N. 2017. The Relation between International Tourism and Economic Growth. Journal of Tourism \& Hospitality, 6(4), 1-7.

Tabash, I.M. 2017. The Role of Tourism Sector in Economic Growth: An Empirical Evidence from Palestine. International Journal of Economics and Financial Issues, 7(2), 103-108.

Tang, C.F., Tan, E.C. 2015. Does tourism effectively stimulate Malaysia's economic growth? Tourism Management. 46(C), 158-163.

Tuncay, N., Ozcan C.C. 2020. The effect of Dutch Disease in the tourism sector: the case of Mediterranean Countries. Tourism and Hospitality Management, 26(1), 99-114.

Usmani, G., Akram, V., Parveen, B. 2020. Tourist arrivals, international tourist expenditure, and economic growth in BRIC countries. Journal of Public Affairs, 1-8.

Wang, W., Ma, H. 2015. An Econometric Analysis of the Relationship between GDP and Tourism Income in Guizhou, China. International Journal of Business Administration, 6(4), 41-47.

UNWTO. 2019. https://www.e-unwto.org/doi/pdf/10.18111/9789284421152

WTTC. 2019. https://wttc.org/Research/Economic-Impact 